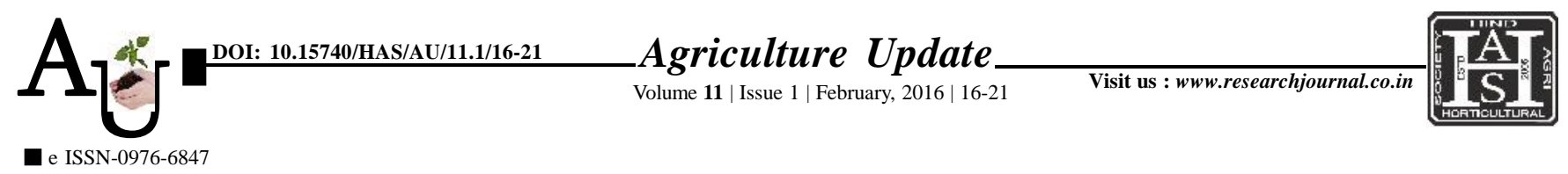

\title{
Research Aвтicle: Performance of migratory apiary units in Sri Muktsar Sahib district of Punjab
}

口 KARAMJIT SHARMA, GURMAIL SINGH AND N.S. DHALIWAL

Article Chronicle: Received :

09.12.2015;

Revised :

21.12.2015;

Accepted :

07.01.2016

KEY WoRDS :

Apiary, Beekeeper,

Migratory, Sri

Muktsar Sahib

Author for correspondence :

GURMAIL SINGH

Krishi Vigyan Kendra

(P.A.U.), Sri Muktsar

Sahib, (Goneana)

(PUNJAB) INDIA

Email: gurmailent@

pau.edu

See end of the article for

authors' affiliations
SUMMARY : The study was conducted during the year 2013-14 and 2014-15 in Sri Muktsar Sahib district of Punjab state. Objective of the study was to study the economic performance of migratory apiary units. Total 45 respondents were selected for the purpose of the study. The analysis of the personal characteristics of the respondents revealed that migratory apiary units were adopted by unemployed rural youth from all the sections of the rural society. Bee keepers from the district migrate to adjoining Haryana and Rajasthan states during the dearth of flora in district Sri Muktsar Sahib of Punjab. The study revealed that mainly three routes were followed by beekeepers of Sri Muktsar Sahib district Punjab. The average number of honey harvests varied from 8.5-11.0 year ${ }^{-1}$ with average honey production of $29-45 \mathrm{~kg} \mathrm{hive}^{-1}$. It was maximum in case of bee keepers migrating to Kota district of Rajasthan (Group II) in winter period. The average number of honey harvests was 9 year ${ }^{-1}$ with average honey production of $35 \mathrm{~kg} \mathrm{hive}^{-1}$ in case of bee keepers migrating to Ganga Nagar district of Rajasthan (Group I) in winter period. Total income per hive was maximum in Group II (Rs. 3812.8) followed by Group I (2946.2) and Group III (2406.8).

How to cite this article : Sharma, Karamjit, Singh, Gurmail and Dhaliwal, N.S. (2016). Performance of migratory apiary units in Sri Muktsar Sahib district of Punjab. Agric. Update, 11(1): 16-21. 